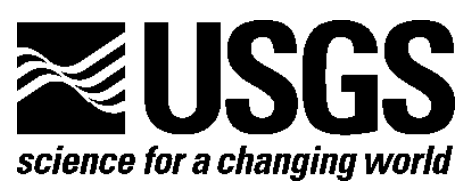

Prepared in cooperation with U.S. Bureau of Reclamation and National Park Service

\title{
Airborne Electromagnetic and Magnetic Survey Data of the Paradox and San Luis Valleys, Colorado
}

By Lyndsay B. Ball, Benjamin R. Bloss, Paul. A. Bedrosian, V.J.S. Grauch, and Bruce D. Smith

Open-File Report 2015-1024

U.S. Department of the Interior

U.S. Geological Survey 


\section{U.S. Department of the Interior \\ SALLY JEWELL, Secretary}

\section{U.S. Geological Survey \\ Suzette M. Kimball, Acting Director}

U.S. Geological Survey, Reston, Virginia: 2015

For more information on the USGS—-the Federal source for science about the Earth, its natural and living resources, natural hazards, and the environment-visit http://www.usgs.gov or call 1-888-ASK-USGS

For an overview of USGS information products, including maps, imagery, and publications, visit http://www.usgs.gov/pubprod

To order this and other USGS information products, visit http://store.usgs.gov

Suggested citation:

Ball, L.B., Bloss, B.R., Bedrosian, P.A., Grauch, V.J.S., and Smith, B.D., 2015, Airborne electromagnetic and magnetic survey data of the Paradox and San Luis Valleys, Colorado: U.S. Geological Survey Open-File Report 2015-1024, 19 p., http://dx.doi.org/10.3133/ofr20151024.

ISSN 2331-1258 (online)

Any use of trade, product, or firm names is for descriptive purposes only and does not imply endorsement by the U.S. Government.

Although this report is in the public domain, permission must be secured from the individual copyright owners to reproduce any copyrighted material contained within this report. 


\section{Contents}

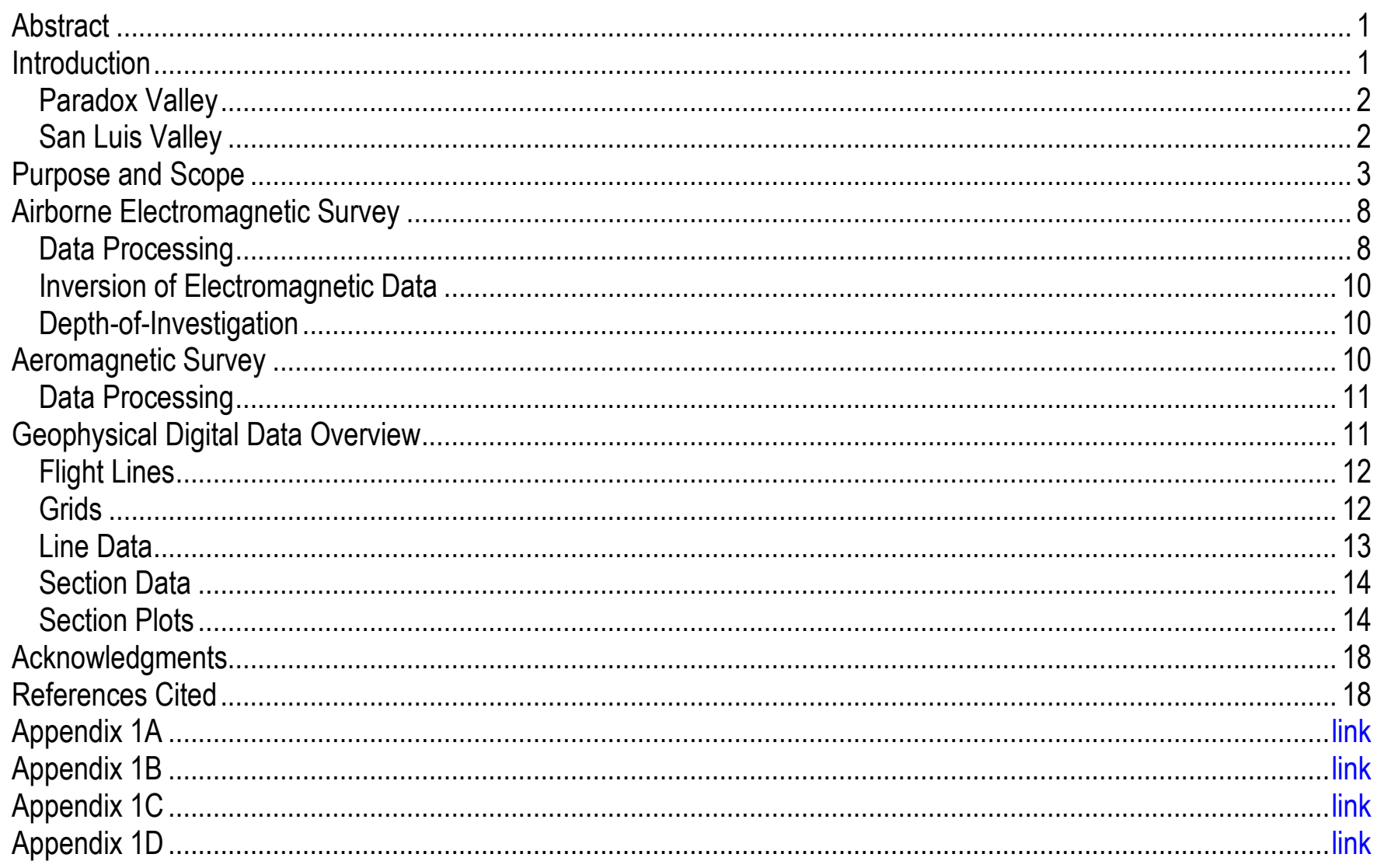

\section{Figures}

1. Maps showing the location of geophysical surveys for the Paradox Valley and the San Luis Valley .............5

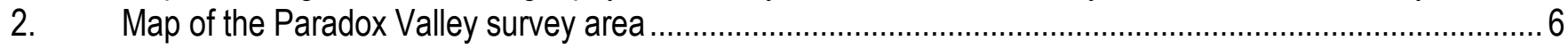

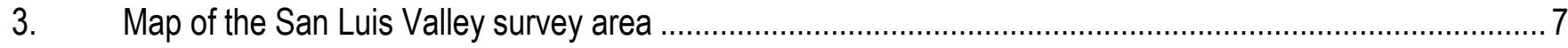

4. An example of the oscillating noise signal .....................................................................................

5. Example inverted resistivity depth slice between 21 and $28 \mathrm{~m}$ depth from the 19-layer $\mathrm{SCl}$ inversion

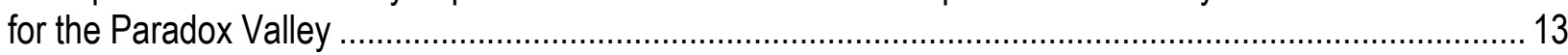

6. Example inverted resistivity depth slice between 46 and $57 \mathrm{~m}$ depth from the 19-layer SCl inversion

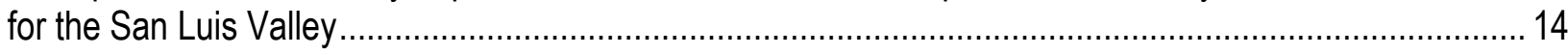

7. Example of inverted resistivity section plot for the Paradox Valley .......................................................... 16

8. Example of inverted resistivity section plot for the San Luis Valley.......................................................... 17

\section{Tables}

1. Line number organization for various survey line types .................................................................. 4

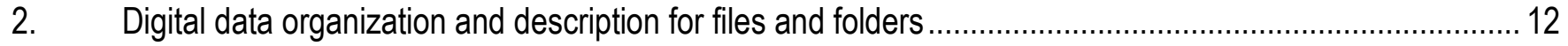




\section{Conversion Factors}

SI to Inch/Pound

\begin{tabular}{lcl}
\hline \multicolumn{1}{c}{ Multiply } & \multicolumn{1}{c}{ By } & \multicolumn{1}{c}{ To obtain } \\
\hline meter $(\mathrm{m})$ & 3.281 & foot $(\mathrm{ft})$ \\
kilometer $(\mathrm{km})$ & 0.6214 & mile $(\mathrm{mi})$ \\
square meter $\left(\mathrm{m}^{2}\right)$ & 0.0002471 & acre \\
square kilometer $\left(\mathrm{km}^{2}\right)$ & 247.1 & acre \\
nanotesla $(\mathrm{nT})$ & 1 & gamma \\
\hline
\end{tabular}

Temperature in degrees Celsius $\left({ }^{\circ} \mathrm{C}\right)$ may be converted to degrees Fahrenheit $\left({ }^{\circ} \mathrm{F}\right)$ as follows:

$$
{ }^{\circ} \mathrm{F}=\left(1.8 \mathrm{x}^{\circ} \mathrm{C}\right)+32
$$

Electrical conductivity is given in millisiemens per centimeter $(\mathrm{mS} / \mathrm{cm})$ unless otherwise specified.

Electrical resistivity is given in ohm-meters (ohm-m) unless otherwise specified.

Electrical resistivity $(\rho$, ohm-m) can be converted to conductivity $(\sigma, \mathrm{mS} / \mathrm{cm})$ as follows:

$$
\sigma=\frac{10}{\rho}
$$

Vertical coordinate information is referenced to the North American Vertical Datum of 1988 (NAVD88).

Horizontal coordinate information is referenced to the North American Datum of 1983, Universal Transverse Mercator projection, Zones 12 north (Paradox Valley; UTM12N) and 13 north (San Luis Valley; UTM13N).

\section{Initialisms Used in This Report}

$\begin{array}{ll}\text { AEM } & \text { airborne electromagnetic } \\ \text { DEM } & \text { digital elevation model } \\ \text { DOI } & \text { depth-of-investigation } \\ \text { EM } & \text { electromagnetic } \\ \text { FEM } & \text { frequency-domain electromagnetic } \\ \text { GPS } & \text { global positioning system } \\ \text { GRSA } & \text { Great Sand Dunes National Park and Preserve } \\ \text { IGRF } & \text { International Geomagnetic Reference Field } \\ \text { LCI } & \text { laterally constrained inversion } \\ \text { NPS } & \text { National Park Service } \\ \text { SCI } & \text { spatially constrained inversion } \\ \text { TDS } & \text { total dissolved solids } \\ \text { TEM } & \text { time-domain electromagnetic } \\ \text { USBR } & \text { U.S. Bureau of Reclamation } \\ \text { USGS } & \text { U.S. Geological Survey }\end{array}$

\section{Abbreviations Used in This Report}

Rx receiver

Tx transmitter 


\title{
Airborne Electromagnetic and Magnetic Survey Data of the Paradox and San Luis Valleys, Colorado
}

\author{
By Lyndsay B. Ball, Benjamin R. Bloss, Paul A. Bedrosian, V.J.S. Grauch, and Bruce D. Smith
}

\begin{abstract}
In October 2011, the U.S. Geological Survey (USGS) contracted airborne magnetic and electromagnetic surveys of the Paradox and San Luis Valleys in southern Colorado, United States. These airborne geophysical surveys provide high-resolution and spatially comprehensive datasets characterizing the resistivity structure of the shallow subsurface of each survey region, accompanied by magnetic-field information over matching areas. These data were collected to provide insight into the distribution of groundwater brine in the Paradox Valley, the extent of clay aquitards in the San Luis Valley, and to improve our understanding of the geologic framework for both regions. This report describes these contracted surveys and releases digital data supplied under contract to the USGS.
\end{abstract}

\section{Introduction}

In October 2011, the U.S. Geological Survey (USGS) contracted airborne electromagnetic (AEM) and magnetic surveys over portions of the Paradox and San Luis Valleys in southern Colorado, United States (fig. 1). The two survey areas were chosen to dovetail with ongoing geologic research and water-resource management activities at agencies within the U.S. Department of Interior, including the USGS, U.S. Bureau of Reclamation (USBR), and the National Park Service (NPS).

Developing accurate conceptual subsurface geologic and hydrogeologic models is challenging but necessary to responsibly manage groundwater resources. Direct-sampling techniques, such as drilling, provide invaluable information about subsurface hydrogeologic properties. However, these techniques are inherently one-dimensional and lend limited insight to the three-dimensional geologic framework or the spatial extent of sampled hydrogeologic conditions. Geophysical methods are important tools for continuing geologic interpretations between drill holes and below surficial sampling locations. Airborne geophysical methods, in particular, provide greater aperture and spatial continuity than is practically feasible with direct sampling or ground-based geophysical surveys. The airborne platform also allows collection over environmentally sensitive areas or difficult-to-access terrain.

The AEM geophysical methods used in these surveys characterize the electrical resistivity of subsurface materials to depths of up to $300 \mathrm{~m}$, as well as the local variability in the Earth's magnetic field. Variations in electrical resistivity are highly sensitive to variations in the concentration of total dissolved solids (TDS) in groundwater; small percentages of which can dramatically decrease bulk resistivity. Resistivity is also sensitive to the presence of clay or other conductive minerals and to variations in grain-size distribution. Because of these sensitivities, electrical resistivity data are especially advantageous for mapping groundwater salinity and the distributions of clay-rich formations within the shallow subsurface. Additional constraints on interpretations of geologic structures that may have hydrogeologic significance, such as the locations of faults, are provided by the magnetic field variations. 


\section{Paradox Valley}

The Paradox Valley in western Colorado is one of several northwest-trending, elongated, collapsed salt anticlines within the Paradox Basin, a region defined by extensive Pennsylvanian evaporites of the Paradox Formation of the Hermosa Group (Weir and others, 1983) (figs. 1A and 1B). The inflow of relatively fresh groundwater through the overlying unconsolidated Quaternary deposits dissolves the Paradox Formation salt, which comprises the core of the Paradox Valley anticline. This dissolution has led to the development of a sodium-chloride-dominated brine plume in the central part of the Paradox Valley, where groundwater TDS concentrations exceed 250,000 milligrams per liter (mg/L) (Watts, 2000; Chafin, 2002).

The Dolores River, a tributary to the Colorado River, flows across the axis of the Paradox Valley and acts as a natural groundwater discharge location. The Dolores River experiences substantial increases in salinity as it intercepts the brine, with historical TDS loads estimated to be about 115,000 tons/year (Chafin, 2002). Salinity is a primary water-quality concern in the Colorado River Basin, resulting in costly damages to industrial, municipal, and agricultural systems each year.

Under the Colorado River Basin Salinity Control Act, the USBR constructed and operates a salinity control project, the Paradox Valley Unit, to reduce salinity loads to the Dolores River. The project consists of a series of shallow pumping wells designed to intercept the brine before it flows into the river. The produced brine is treated and injected into confined Precambrian and Paleozoic rocks at around $4.5 \mathrm{~km}$ depth. The control project began production operation in 1996 and has succeeded in reducing river salinity, with an estimated 90-percent reduction in annual TDS loads as of 2001 (Chafin, 2002). However, the injection-well system is nearing the end of its useful life, and the USBR is exploring alternative strategies to reduce the salinity loads to the Dolores as well as alternative disposal methods. The USGS is assisting the USBR in these efforts through the development of a variabledensity groundwater flow model and supporting hydrogeologic characterization.

The sensitivities of AEM data to changes in TDS and lithologic composition make resistivitybased interpretations ideal for defining the shallow geometry of the brine plume and refining the geometry of hydrostratigraphic units in freshwater regions of the valley. In October 2011, the USGS contracted an AEM and aeromagnetic survey of the Paradox Valley. Data were collected over 1,200 line $\mathrm{km}$ through a series of northwest-trending block lines paralleling the axis of the valley with a nominal spacing of $150 \mathrm{~m}$ and a nominal altitude of $40 \mathrm{~m}$ above the ground (fig. 2). Tie lines were collected perpendicular to these block lines with 2-km spacing. Two smaller blocks were flown in addition to the main valley block: northwest of the valley surrounding Buckeye Reservoir and extending into eastern Utah, and a small area near the downstream reach of the Dolores River on the northeastern margin of the Paradox Valley. This dataset can be used to define the electrical resistivity of the subsurface to depths approaching $300 \mathrm{~m}$ in parts of the basin. These data provide a new and spatially comprehensive view into the hydrogeology of the Paradox Valley and are intended to help improve the predictive certainty of the groundwater flow model.

\section{San Luis Valley}

Agricultural and ranching communities in San Luis Valley, south-central Colorado, depend on groundwater that resides in a geologically complex alluvial basin that is part of the northern Rio Grande rift (figs. $1 A$ and $1 C$ ). This area of the valley is a particular focus because the development of effective water management strategies requires an improved understanding of the local hydrogeology and geology, particularly in the context of continued drought conditions and recent legal actions to obtain water rights at Great Sand Dunes National Park and Preserve (GRSA). The GRSA and surrounding area were chosen as an airborne geophysical survey site to investigate several aspects of the hydrogeologic 
framework controlling groundwater flow: (1) regionally extensive clay aquitards, (2) uplifted basement blocks that obstruct regional groundwater flow, (3) buried volcanic layers that can impede or facilitate groundwater flow, and (4) intrabasin faults that offset the clay or volcanic layers.

The primary objective of the airborne survey is to map the extent and depth of regionally extensive clay aquitards that separate basin sediments into upper unconfined and lower confined aquifers. Wells drilled into the lower aquifer are strictly regulated, and knowledge of the extent and depth of the clay layers is limited. In addition to its hydrogeologic significance as a regional confining unit, the clay layers are important markers in studying the interaction between sedimentation of Lake Alamosa and faulting of the Rio Grande rift. The clay layers were deposited within Lake Alamosa, a Pliocene and Pleistocene lake that covered much of the modern San Luis Valley and experienced multiple transgressions and regressions over its roughly 3-million-year lifetime (Machette and others, 2013).

The airborne platform is particularly advantageous for surveying the GRSA where the sand dunes make ground surveys infeasible. AEM data were collected over 1,600 line $\mathrm{km}$ in a series of block, tie, and reconnaissance lines (fig. 3). The majority of data (1,494 line km) were collected over a 36.5by $20.5-\mathrm{km}$ area with nominal 300-m line spacing within the block and 3-km spacing between tie lines. An additional 105 line $\mathrm{km}$ were flown as reconnaissance lines collected south of the San Luis Valley block (fig. 3). Lines were nominally flown $30 \mathrm{~m}$ above ground.

The AEM survey was designed to follow up on ground geophysical results and supplement other airborne geophysical surveys conducted by the USGS in the area (Bankey and others, 2004; Drenth and others, 2009, 2013; Fitterman and Grauch, 2010). In particular, resistivity models derived from groundbased time-domain electromagnetic (TEM) data collected prior to the AEM survey revealed a pervasive, electrically conductive layer corresponding to a distinctive section of massive clay found in water wells in the area (Fitterman and de Souza Filho, 2009). The main block of the present AEM survey was designed to develop a more comprehensive view of this electrically conductive layer and tie the information to the few deep water and oil-exploration wells located in the area. The one north-south and four east-west reconnaissance lines, located south of the main block (fig. 3), were designed to connect the main block to several geologic and geophysical features of interest, including a well-studied core hole located at the west end of the southernmost east-west line (Rogers and others, 1992).

\section{Purpose and Scope}

This report releases digital geophysical data provided to the USGS for the Paradox and San Luis Valleys. The methodology used to collect and process these data is presented in the Airborne Electromagnetic Survey and Aeromagnetic Survey sections. The data and file structure are explained in the Geophysical Data Overview section. Geologic or hydrogeologic interpretations of the AEM or ancillary data are beyond the scope of this data release and are not presented in this report. 
Table 1. Line number organization for various survey line types for the Paradox and San Luis Valleys airborne geophysical surveys.

\begin{tabular}{|c|c|}
\hline Line type & Line number range \\
\hline \multicolumn{2}{|c|}{ Paradox Valley } \\
\hline Block line (main valley) & $100202-106302$ \\
\hline Block line (Buckeye Reservoir) & $150101-152401$ \\
\hline Tie line (main valley) & $200101-200801$ \\
\hline Tie line (Buckeye Reservoir) & $250101-250301$ \\
\hline Block line (Dolores Canyon) & $350101-351301$ \\
\hline Reconnaissance line & $600100-600103$ \\
\hline Calibration line & 990101-990106 \\
\hline \multicolumn{2}{|c|}{ San Luis Valley } \\
\hline Block line & $100101-110801$ \\
\hline Tie line & 200201-200401 \\
\hline Reconnaissance line & $300101-300501$ \\
\hline Calibration line & 990101-990106 \\
\hline
\end{tabular}


A $110^{\circ} \mathrm{W}$

$109^{\circ} \mathrm{W}$

$108^{\circ} \mathrm{W}$

$107^{\circ} \mathrm{W}$

$106^{\circ} \mathrm{W}$

$105^{\circ} \mathrm{W}$

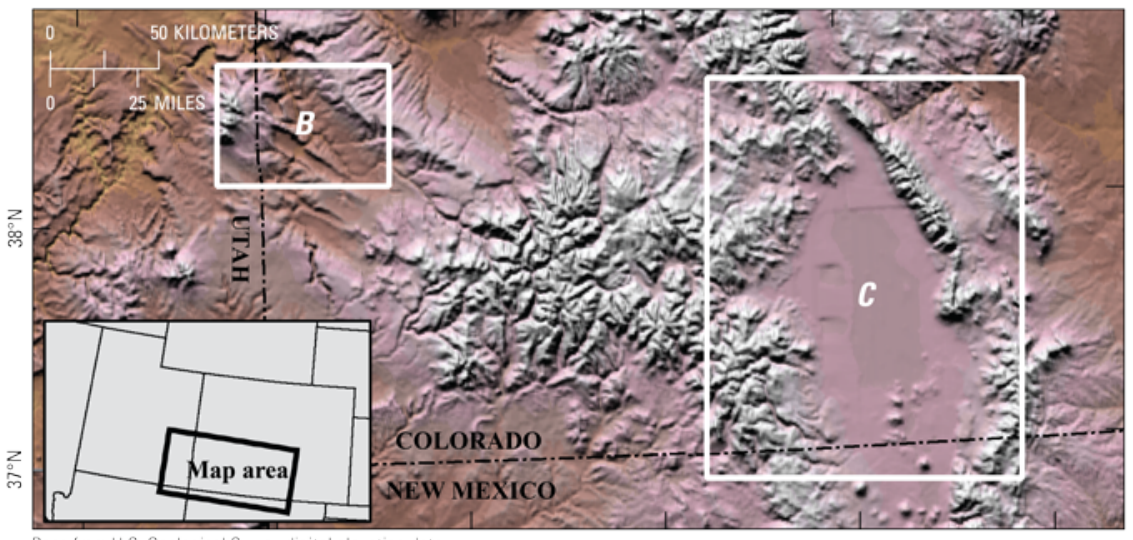

Base from U.S. Geological Survey digital elevation data

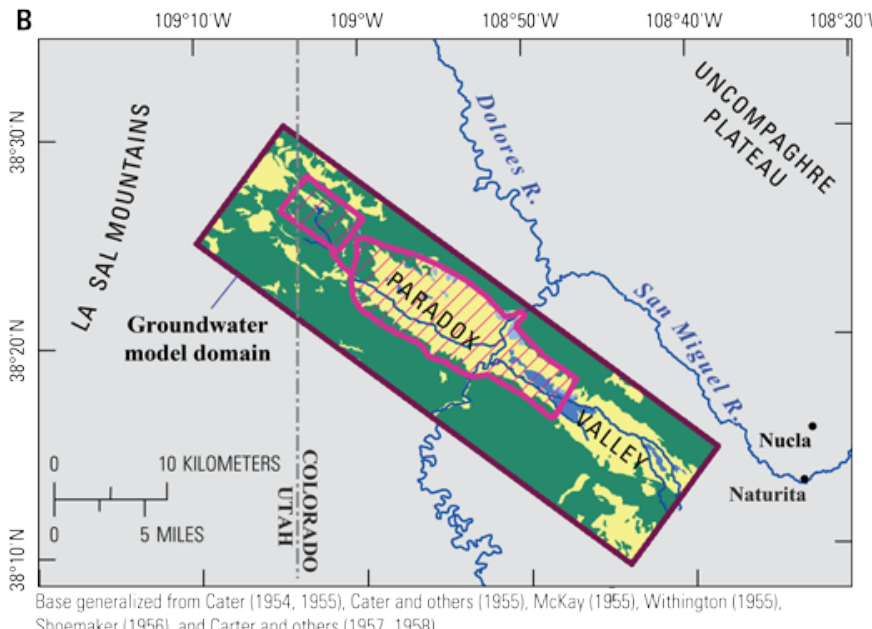

EXPLANATION

\section{Geologic units}

Quaternary sediment

Cretaceous - Permian sedimentary rocks

Pennsylvanian sedimentary rocks

Pennsylvanian Paradox Formation of Hermosa Group

Airborne geophysical survey

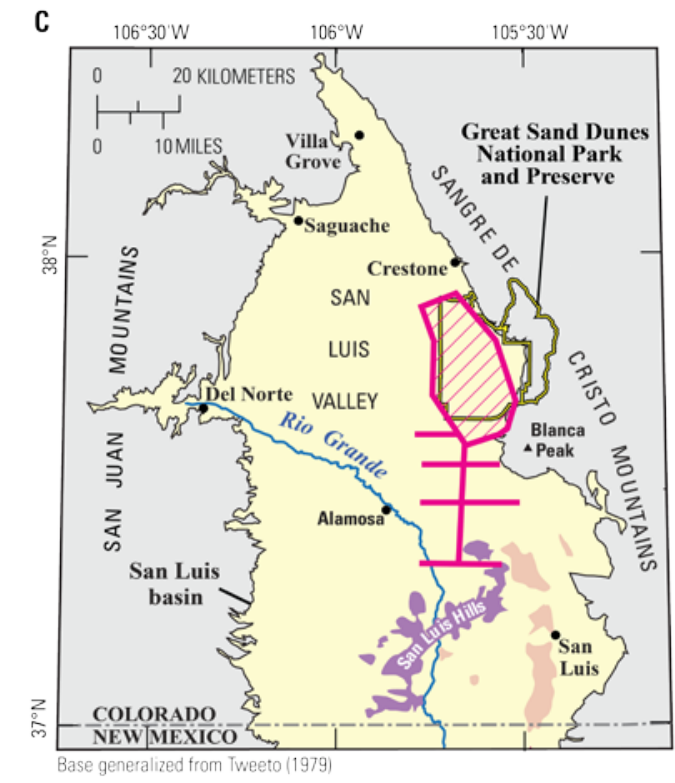

Geologic units

Alluvial and colluvial sediment

Syn-rift basalt

Pre-rift volcanic rocks

Airborne geophysical survey

Figure 1. Maps showing (A) location of geophysical surveys for (B) Paradox Valley and $(C)$ San Luis Valley and Great Sand Dunes National Park and Preserve. Paradox Valley bedrock geology summarized by K. Watts (USGS, written commun., November 2013). 


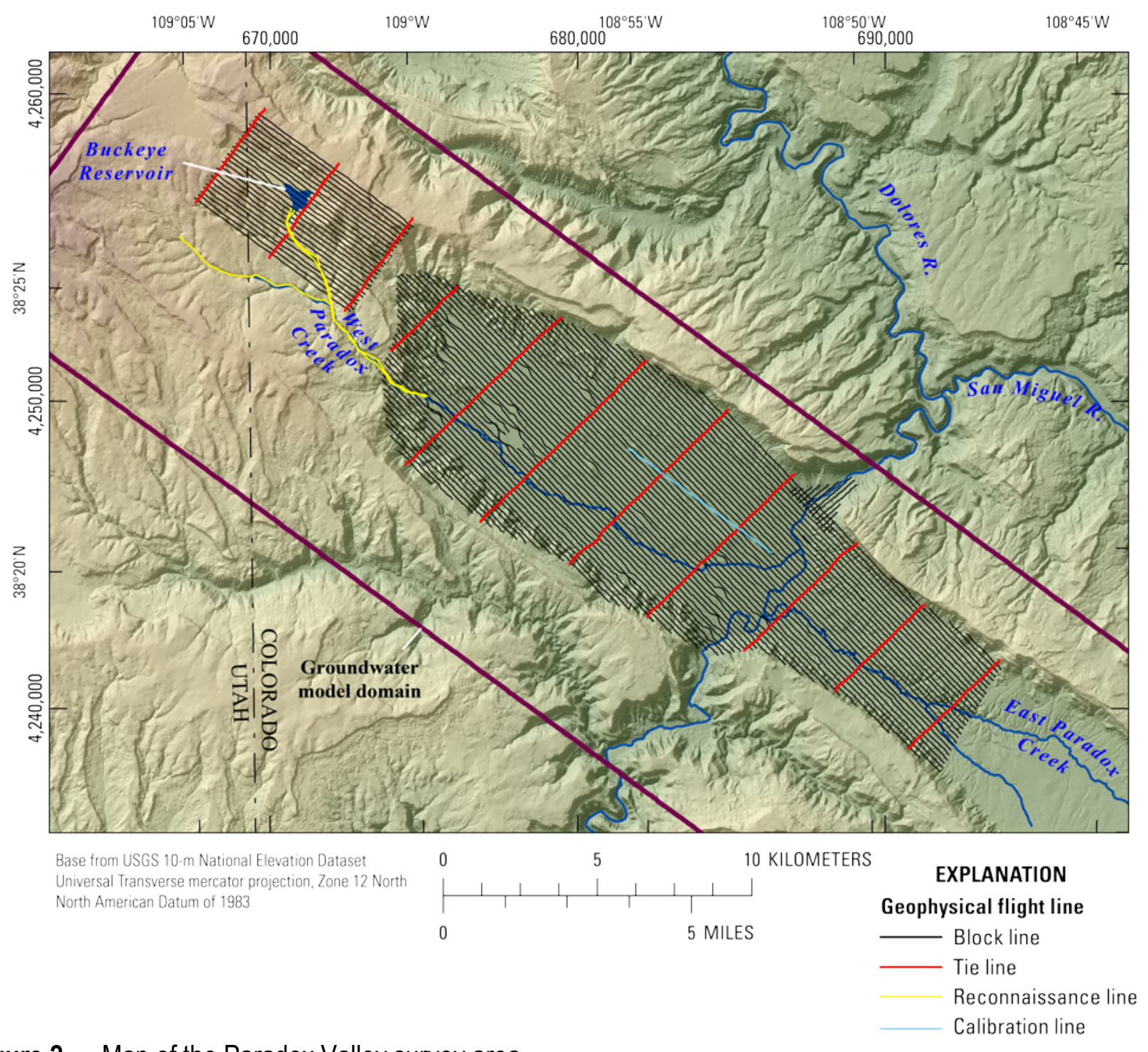

Figure 2. Map of the Paradox Valley survey area. 


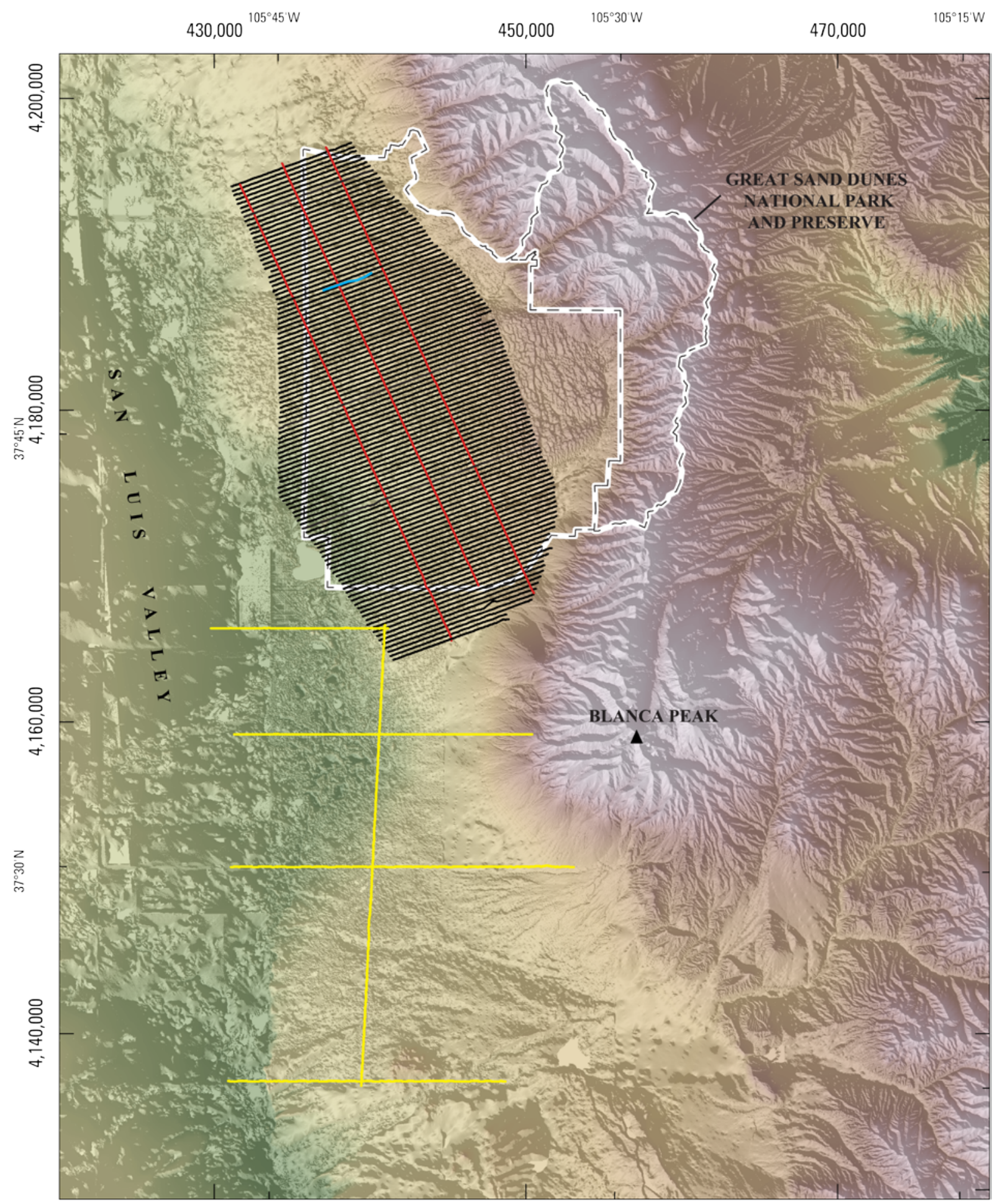

Base from USGS 30-m National Elevation Dataset

Universal Transverse mercator projection, Zone 13 North

North American Datum of 1983

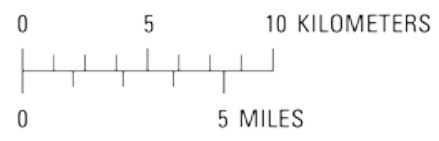

EXPLANATION

Geophysical flight line

- Block line

Tie line

Reconnaissance line

Calibration line

Figure 3. Map of the San Luis Valley survey area. 


\section{Airborne Electromagnetic Survey}

Subsurface resistivity structure can be estimated using a variety of approaches, including electromagnetic (EM) methods. EM systems transmit an electromagnetic field from a transmitter (Tx) loop or coil, inducing an electric current within the Earth. The interaction of the Earth with the induced current is dependent on the subsurface resistivity and gives rise to magnetic and electric fields that can be sensed by one or more receiver $(\mathrm{Rx})$ loops or coils. EM systems can be deployed from aircraft by mounting Tx and Rx loops to a rigid frame. Ancillary positional information is obtained via additional sensors on the air frame and aircraft, including one or more high-precision global positioning systems (GPS) for geospatial positioning, a laser altimeter for altitude, and one or more inclinometers for attitude of the air frame.

Two basic types of AEM systems, both operating on the same physical principle, are commonly used for hydrogeophysical investigations. Frequency-domain electromagnetic (FEM) systems transmit a continuous sinusoidal current and measure the earth response in the "on-time," while current is passing through the Tx loop. TEM systems transmit pulses of current and measure the earth response in the "offtime" over a series of time gates following the end of current transmission, when no current is present in the Tx loop. Generally speaking, FEM systems have superior near-surface resolution, whereas TEM systems have a greater depth of investigation. For the Paradox and San Luis Valleys, the depth of the targeted hydrogeologic features led to the selection of a TEM system. The helicopter-borne SkyTEM system was flown under contract by SkyTEM Surveys ApS (Aarhus, Denmark) in October 2011. A detailed description of data acquisition and SkyTEM system parameters are documented in the SkyTEM Acquisition Report (appendix 1A).

\section{Data Processing}

AEM data for both survey areas have undergone contractor-performed data processing and inversion to generate resistivity models of the subsurface (discussed in the next section). The contractor base-station corrected and filtered the ancillary positioning data. These data were used to calculate the Tx and Rx geographic location and height above ground, to correct for frame tilt, and to generate a digital elevation model (DEM). Raw EM data were stacked to a 10-hertz (Hz) sample rate, normalized with respect to system parameters, noise filtered, and merged with the processed positioning data. Processed EM and magnetic data are provided in the LINEDATA folder for each survey area. These processing steps are described in detail in the SkyTEM Acquisition Report (appendix 1A).

In addition to the standard processing workflow described above, SkyTEM performed surveyspecific processing for both the San Luis and Paradox Valleys. During inspection and processing of the AEM data, a detrimental and time-varying noise signal was observed in the high-moment EM data for both survey areas. This noise can be observed as an oscillating behavior in the normalized Rx response across all high-moment time gates with a variable period ranging over several seconds (fig. 4). SkyTEM has attributed this noise to $30-\mathrm{Hz}$ mechanical vibrations from the generator transferred to the Rx coil through carrier ropes (discussed in detail in the SkyTEM Acquisition Report and supplemental SkyTEM Technical Note, appendixes 1A and 1B). The broader periodicity of this $30-\mathrm{Hz}$ noise signal is likely the artifact of generator power variations over time and changes in rope tension with movement of the air frame. The effect of this noise on resistivity inverse models is to create geologically unrealistic alternating resistors and conductors at depth. SkyTEM developed a survey-specific processing routine to attempt to remove this noise from the high-moment $\mathrm{Z}$-coil data. The following excerpt from the SkyTEM Acquisition Report (p. 33, appendix 1A) describes this routine: 
"In an effort to determine and subtract the time varying, noise-generated gate offsets, an automated sinusoid fitting and subtraction tool was introduced and applied to the individual soundings prior to stacking. Assuming a constant noise frequency of $30 \mathrm{~Hz}$, while using only the last four gates to calculate least squares fit (in terms of amplitude and phase), it was possible to remove a significant part of the problematic oscillations. The most important prerequisite for the successful application of this noise compensation technique is that the 30 $\mathrm{Hz}$ noise signal must be the dominating signal contribution for the last 4 gates. This requires that the earth response is negligible in order for the sinusoid fit to be unbiased, while unrelated noise contributions will likewise tend to worsen the fit."

Although this technique improved data quality and effectively compensated for the obvious noise impacts on the inversion models (discussed in the Inversion of Electromagnetic Data section), there is also the potential for distortion of late-time data, particularly in conductive areas where the 30$\mathrm{Hz}$ noise may not be the only contribution to the measured response at late-time gates. This is particularly relevant with respect to the electrically conductive Paradox Valley brine plume and the Lake Alamosa clay deposits of the San Luis Valley, leading to potential uncertainty in the interpretation of brine plume and clay layers using these noise-corrected data.

As an alternative to SkyTEM's noise-correction procedure, Aarhus Geophysics ApS performed a separate processing and inversion schematic (Aarhus Geophysics Report, appendix 1C). The Aarhus approach involved a combination of automated and manual filtering and averaging, followed by heavy manual culling of the affected late-time data with iterative evaluation of the result through inversion. Although this technique avoids the possibility for distortion of some late-time data and may produce more reliable inverse models in conductive regions than the correction technique used by SkyTEM, it also results in a reduction in the total depth-of-investigation (DOI) (defined in the Inversion of Electromagnetic Data section) of the inverted model section. This processing routine is described in detail in the Aarhus geophysical reports for Paradox and San Luis Valleys (appendixes 1C and 1D).

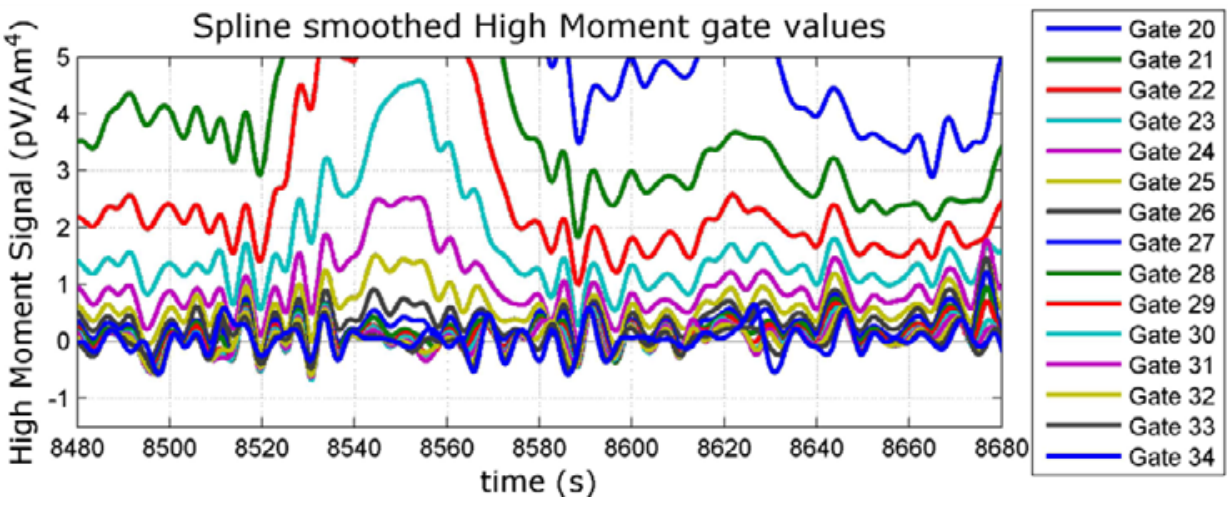

Figure 4. An example of the oscillating noise signal observable between all time gates (from figure 14 of the SkyTEM Acquisition Report, appendix 1A). pV/Am ${ }^{4}$, picovolts per Amps-meter ${ }^{4}$ 


\section{Inversion of Electromagnetic Data}

Inversion is used to estimate the distribution of resistivity with depth at each processed data location, or sounding. Inversions for each survey area were performed using two datasets under the contract: SkyTEM inverted the noise-compensated Z-coil data and Aarhus Geophysics (Aarhus, Denmark) inverted the uncompensated but culled Z-coil data. The inversion program Aarhus Workbench (HydroGeophysics Group, University of Aarhus, Denmark) was used by both contractors. Workbench performs a regularized, damped, least-squares inversion for one-dimensional (1-D) multilayer data. SkyTEM used the laterally constrained inversion (LCI) approach of Auken and others (2005) using a 30-layer model. The LCI approach links 1-D models at neighboring soundings together along flight lines via regularization that enforces lateral continuity. Aarhus Geophysics used a spatially constrained inversion (SCI) approach with a 19-layer model where model parameters for a given sounding are spatially dependent on their neighbors; the regularization constraint between neighboring soundings is scaled according to the inverse distance between neighboring models. Each inversion approach is described in detail by the contractors in their respective reports (appendixes 1 A, 1C, and 1D). These two data processing and inversion approaches have resulted in differences in resistivity structure that may influence interpretation. Both inversion models are released with this report (SECTIONDATA directory for each survey area). The 19-layer SCI inversion based off the $30-\mathrm{Hz}$ noise-culled data is recommended as the most applicable inversion for both study areas, and these inverted section data are also released as depth-slice grids (GRIDS directory) and visualized section data (SECTIONPLOTS directory). However, the most effective processing and inversion strategy for a given part of the survey area is dependent upon the resistivity structure, the local area of interest, the original quality of the data at those locations, and the intended interpretive use.

\section{Depth-of-Investigation}

The strength of measured earth response, and therefore the quality of data, is a function of dataacquisition parameters, flight altitude, recording time following current turn-off, and subsurface resistivity. Calculated depth-of-investigation is a valuable tool for evaluating the reliable depth to which an inverse model is well constrained and can thus be used for geologic interpretation. In the context of regularized inversion, calculated DOI helps discriminate between parts of the inverse model that are determined by the data and those that simply reflect the regularization applied to the inversion. A linear sensitivity-based DOI was calculated for each sounding (Christiansen and Auken, 2012). In this approach, a column-wise sum of the sensitivity matrix is calculated for each layer resistivity within the model. The cumulative sum of the values for each layer resistivity, starting at the bottom of the model, is then used to estimate the DOI.

\section{Aeromagnetic Survey}

Aeromagnetic surveys use a magnetometer attached to an aircraft to measure the variability in the intensity of the Earth's magnetic field over the surveyed area. The relative strength of the magnetic field at a given location depends on the volume and distribution of magnetic minerals in the subsurface, the nature of the magnetic properties of the minerals, and the distance and direction of these minerals relative to the magnetometer. Different geologic formations may vary in mineral composition, and as such, some geologic units have measurable magnetic contrasts. Aeromagnetic data can be useful for mapping surficial and subsurface geology, especially in locating concealed faults and detecting buried igneous and metamorphic rocks. 
The ability to resolve geologic features using gridded aeromagnetic data is largely a function of survey design. Reid (1980) determined that a ratio of line spacing to flight height of 2:1 or less is ideal for properly resolving most near-surface geologic features. If this ratio is not met, the high-frequency information produced by near-surface magnetic sources is lost between flight lines. Grids constructed from such line data improperly connect the data between the flight lines leading to aliasing of highfrequency information into low frequencies and a general noisy appearance.

Defining the resistivity structure was most important to meeting the objectives of airborne geophysical surveys. As such, the surveys were optimized for the EM system, and survey designs do not meet the ideal criteria for resolving near-surface geologic features in gridded magnetic data, despite the low flight heights. The ratios of line spacing to flight height for Paradox Valley and San Luis Valley surveys are 3.75 and 10.0, respectively. The noisy character typical of aliasing problems is most evident in the magnetic grid for the San Luis Valley survey, which has the highest ratio of line spacing to flight height. A previously flown aeromagnetic survey provides better resolution over most of the same area (Drenth and others, 2009). The aliasing problem is not as severe in the Paradox Valley magnetic grid. However, isolated noise spikes are more prevalent and are caused by interference from anthropogenic metal structures.

\section{Data Processing}

Raw total-field magnetic data were interpolated to a $10-\mathrm{Hz}$ sample rate, merged with processed positioning data, corrected for diurnal variations in the magnetic field, heading effects, and the Earth's magnetic field defined by the International Geomagnetic Reference Field (IGRF). Standard tie-line leveling and micro-levelling were then applied to obtain the final residual magnetic data. The IGRF was added back to the residual magnetic data to represent total-field magnetic data. Processed EM and magnetic data are provided in the LINEDATA folder for each survey area. These processing steps are described in detail in the SkyTEM Acquisition Report (appendix 1A).

\section{Geophysical Digital Data Overview}

Digital data provided to the USGS under contract from SkyTEM and Aarhus Geophysics are released with this report for the Paradox and San Luis Valleys study areas. In some instances, the USGS has reformatted these data for consistency, accessibility, and to avoid proprietary data formats. Data are provided in separate directories for each survey area with identical subdirectory structures. Several digital products and data formats have been provided, in addition to the contractor reports (appendix 1). The file structures have been altered from those described by the contractors in appendix 1 for simplicity and file size. These digital data are summarized in table 2 and the following sections. README files in each data subdirectory provide explanations to file naming conventions, projection and datum, and descriptions of channels for tabular data. 
Table 2. Digital data organization and description for files and folders within each survey area subdirectory.

[AEM, airborne electromagnetic; SCI, spatially constrained inversion; Hz, hertz]

\begin{tabular}{|c|c|}
\hline Folder & Description \\
\hline FLIGHTLINE & $\begin{array}{l}\text { Geospatial datasets containing line locations and numbering. Subfolders exist for AutoCAD } \\
\text { files }(* . \mathrm{dxf}) \text {, Esri shape files (*.shp), and GoogleEarth Keyhole Markup Language }\left({ }^{*} . \mathrm{kml}\right) \\
\text { formats. }\end{array}$ \\
\hline GRIDS & $\begin{array}{l}\text { Selected contractor-produced grids of inverted AEM, magnetic and elevation data. All grids } \\
\text { are provided in Geosoft Oasis Montaj }(* \text {.grd) format. Grids are also provided as } \\
\text { georeferenced images in geoTIFF }(* \text {.tif }) \text { and zipped Keyhole Markup Language }\left({ }^{*} . \mathrm{kmz}\right) \\
\text { formats. }\end{array}$ \\
\hline LINEDATA & Corrected and culled AEM and aeromagnetic data in ASCII standard (*.xyz) format. \\
\hline SECTIONPLOTS & $\begin{array}{l}\text { Images of inverted resistivity sections from the 19-layer SCI inversion of } 30-\mathrm{Hz} \text { noise culled } \\
\text { AEM data (*.pdf). }\end{array}$ \\
\hline SECTIONDATA & $\begin{array}{l}\text { Databases of the corrected and culled inverted resistivity depth models (INV_CORRECTED } \\
\text { and INV_CULLED, respectively) in ASCII standard (*.xyz) format. }\end{array}$ \\
\hline
\end{tabular}

\section{Flight Lines}

The FLIGHTLINE folder contains geospatial datasets of the flight-line paths. The flight-line location files are formatted in AutoCAD (*.dxf) format, Esri Shapefile (*.shp and associated files) format, and in GoogleEarth Keyhole Markup Language (*.kml) format.

\section{Grids}

The GRIDS folder contains interpolated grids of various channels of magnetic and ancillary data: residual magnetic field, total magnetic field intensity (GRID_MAG folder), and the DEM developed using GPS and altimeter data (GRID_DEM folder). Gridded depth slices through inverted resistivity models have also been generated by the USGS for the 19-layer SCI inversion and 30-layer LCI inversion above the depth at which the majority of the study area falls below the DOI calculated during the inversion process (GRID_19LInvSCI and GRID_30LInvSCI folders). These depth slices were generated using the minimum-curvature application (Webring, 1981) with 50-m grid-cell lengths and are blanked where the layer falls below the depth of investigation. Figures 5 and 6 show examples of these inverted resistivity depth-slice grids for each survey area.

Grids are provided in three formats: numerical data are provided in Geosoft grid (*.grd) format; images of these grids are provided in georeferenced geoTIFF (*.tif) and zipped Keyhole Markup Language $(* . \mathrm{kmz})$ formats. The nomenclature for the grid names is given in the README file within the GRIDS folder. The numerical Geosoft grids can be viewed and analyzed in free software distributed by Geosoft (http://www.geosoft.com/support/downloads/viewers/oasis-montaj-viewer) or in various other mapping software packages using free plug-ins provided by Geosoft

(http://www.geosoft.com/downloads). For example, the Geosoft-formatted grids can be viewed directly in the Esri ArcMap application with the Geosoft ArcGIS plug-in

(http://www.geosoft.com/support/downloads/plug-ins/plug-arcgis). Once the plug-in is installed and loaded in ArcMap, Geosoft grids can be handled within ArcMap in a similar manner to other types of raster data. GeoTIFF images can be viewed in most standard geographic information system software. 
Keyhole Markup Language images can be viewed using GoogleEarth software freely distributed by Google (http://www.google.com/earth/).

\section{Line Data}

The LINEDATA folder contains AEM and aeromagnetic survey data. With respect to the EM data, three databases are present for each survey area representing the raw data, the $30-\mathrm{Hz}$ noise compensated data, and the noise-culled data. The data are presented in ASCII (*.XYZ) format with column headings as described in the README file within the LINEDATA folder. The SkyTEM acquisition report (appendix 1A) also describes the digital flight-line data.

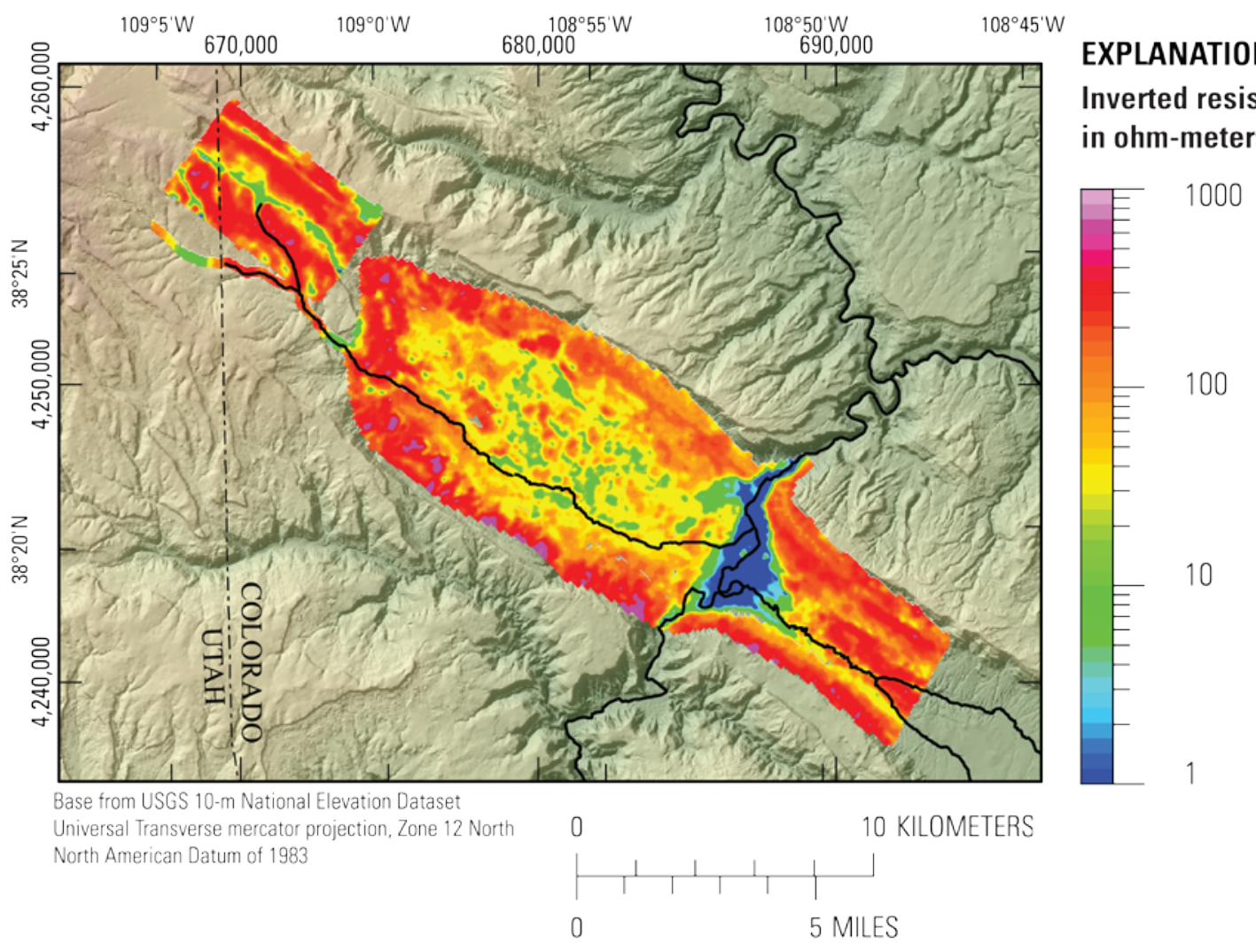

Figure 5. Example inverted resistivity depth slice between 21 and $28 \mathrm{~m}$ depth from the 19-layer SCl (spatially constrained inversion) for the Paradox Valley. Depth slices from additional layers are provided in multiple formats in the GRIDS subdirectory. 


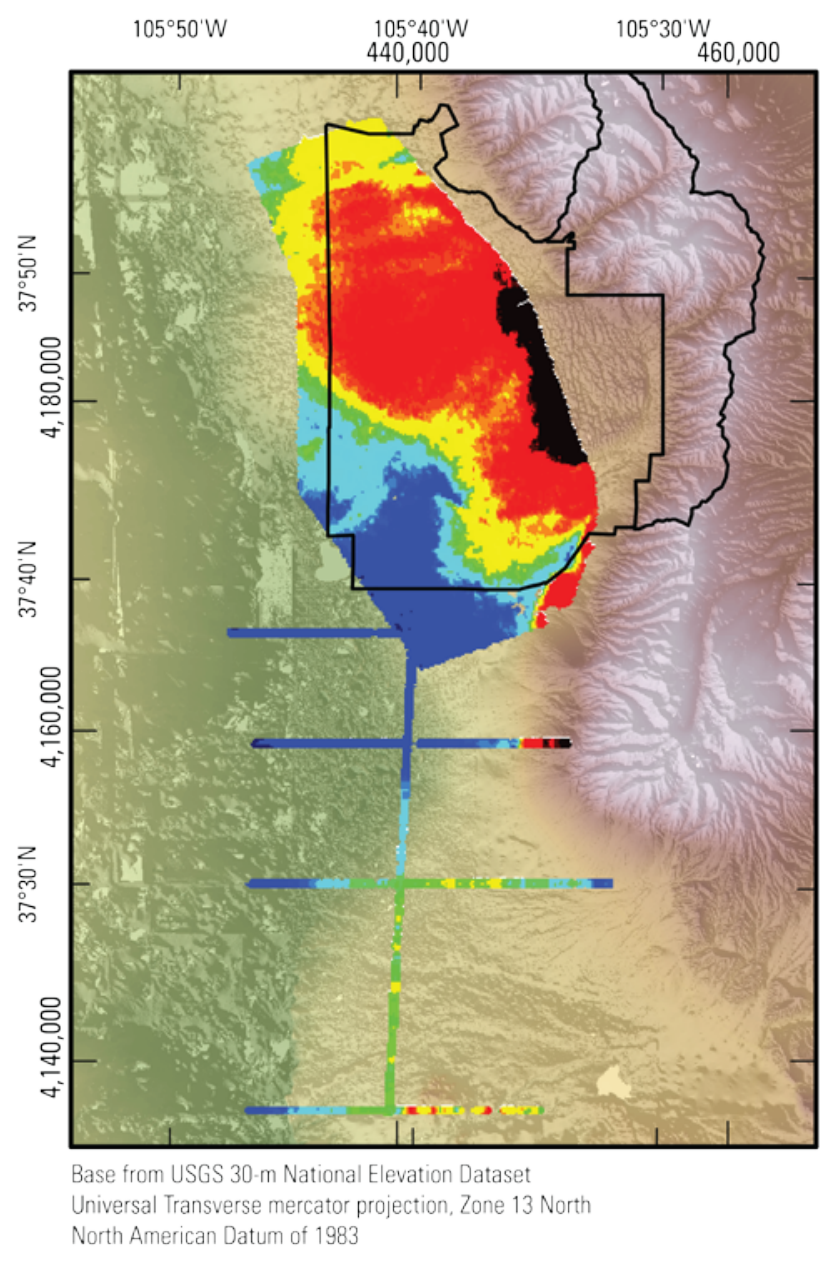

EXPLANATION

Inverted resistivity

in ohm-meters

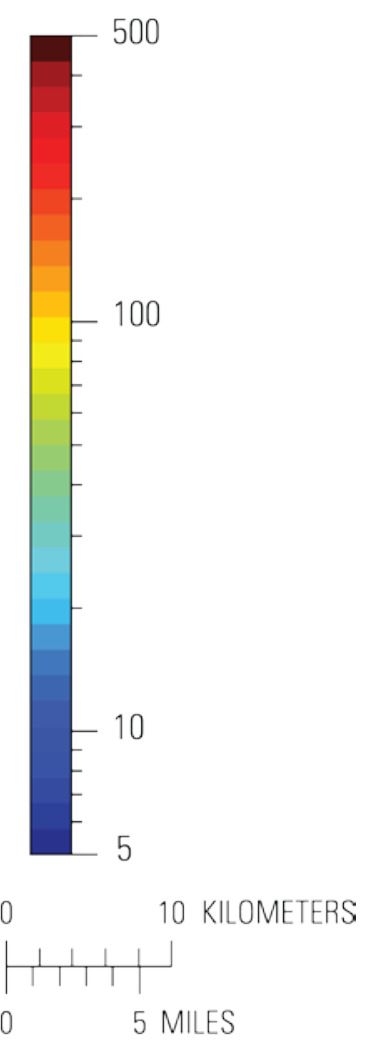

Figure 6. Example inverted resistivity depth slice between 46 and $57 \mathrm{~m}$ depth from the 19-layer SCI (spatially constrained inversion) for the San Luis Valley. Depth slices from additional layers are provided in multiple formats in the GRIDS subdirectory.

\section{Section Data}

The SECTIONDATA folder contains the inverted resistivity data as a function of depth along the flight lines, as determined from the previously described inversion processes. Two databases are present for each survey area representing the LCI inversion of the $30-\mathrm{Hz}$ noise compensated data and the 19-layer SCI inversion of the noise-culled data. The depth intervals for each inversion model layer (DepTop and DepBot channels) are relative to land surface. Land-surface elevation along flight lines are defined by the GPS-derived DEM and is specified in meters relative to the North American Vertical Datum of 1988 (NAVD88).

\section{Section Plots}

The SECTIONPLOTS folder contains USGS-generated figures of inverted resistivity section data resulting from the 19-layer SCI inversion of the 30-Hz noise-culled AEM dataset. Each survey area has been displayed at independent color scales intended to be useful for the interpretive goals of the 
ongoing research in both areas. For the Paradox Valley, a logarithmic scale from 1 to 1,000 ohm-m is shown to illustrate the contrasts between different geologic units and the Paradox Valley brine plume (fig. 7). For the San Luis Valley, logarithmic color scales from 5 to 100 and 5 to 500 ohm-m are shown to illustrate the sand-clay and sediment-bedrock geologic contacts, respectively (fig. 8). Inverted resistivity section data are also displayed in the contractor's reports (appendix 1). Note that resistivity values falling above or below the limits of the color scales are colored the same as the maximum or minimum limits, respectively.

The DOI is a useful tool when displaying the final inverted resistivity sections because it provides a means for evaluating areas of confidence in the inverted model. In the SECTIONPLOTS folder, inverted resistivity sections for the Aarhus SCI inversion are shown with a semitransparent mask applied below the DOI. As such, the portions of the inverted model that are well-constrained by the measured data are shown in full-strength color, while the poorly constrained portions are obscured. The uneven "ragged" DOI seen in some sections is in part the result of the $30-\mathrm{Hz}$ culling routine applied to the data prior to the SCI inversion. 


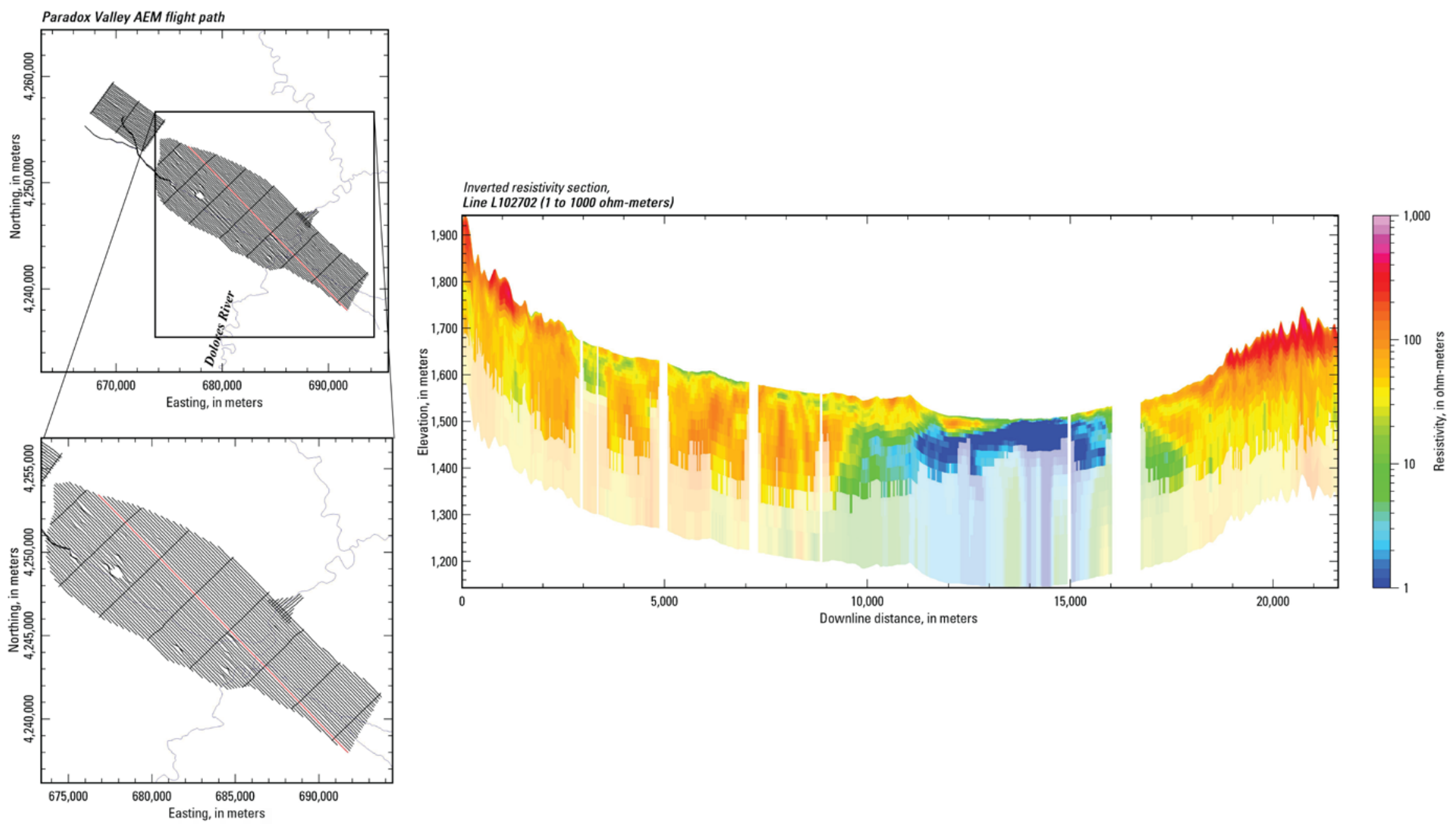

Figure 7. Example of inverted resistivity section plot for the Paradox Valley. Plots for all sections can be found in the SECTIONPLOTS subdirectory. 

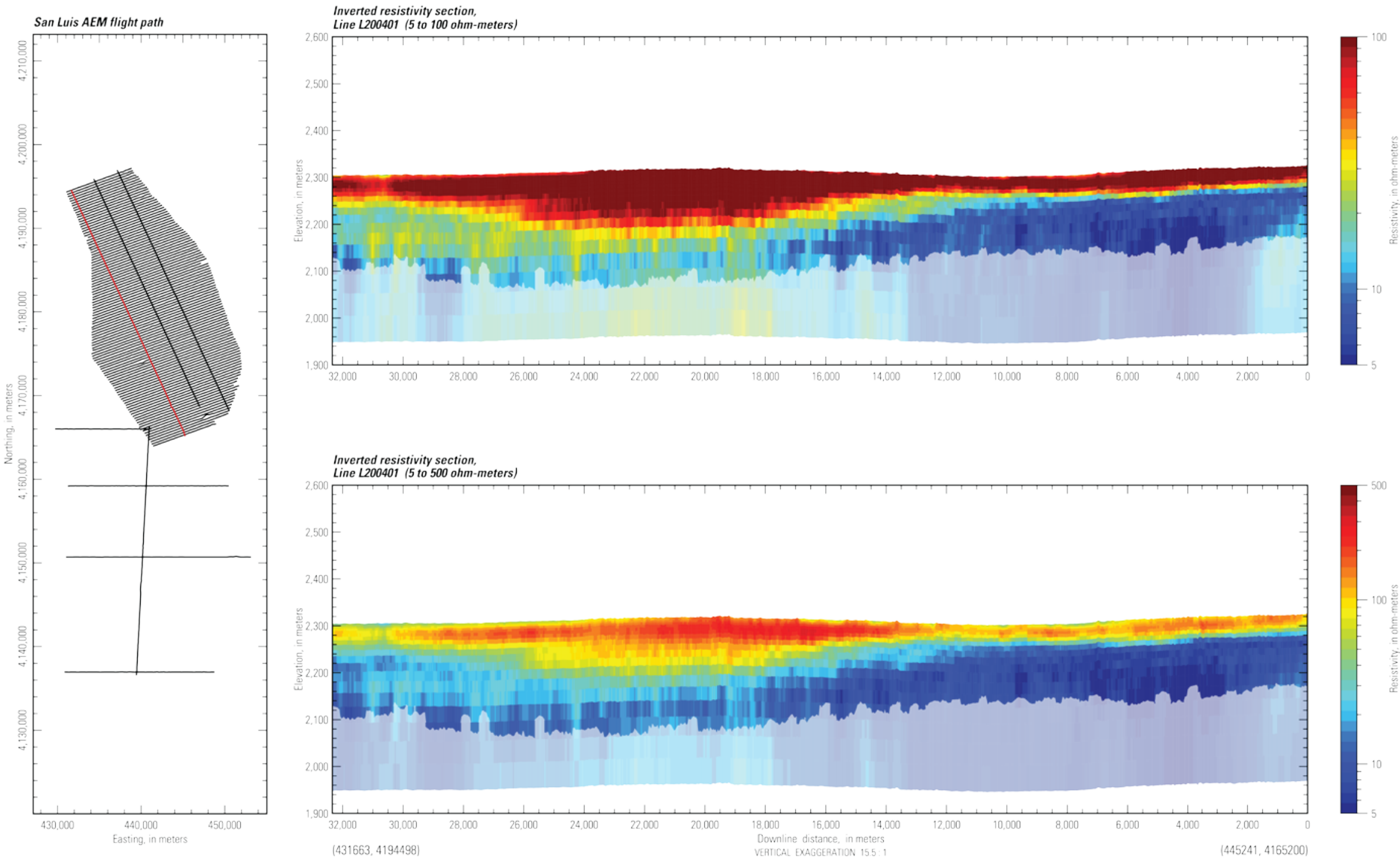

Figure 8. Example of inverted resistivity section plot for the San Luis Valley. Plots for all sections can be found in the SECTIONPLOTS subdirectory. AEM, airborne electromagnetic. 


\section{Acknowledgments}

The authors acknowledge the efforts of Jared Abraham (formerly USGS), Ben Drenth (USGS), and Ken Watts (USGS) in the design and contracting of these surveys. Appreciation is extended to Andrew Nicholas (USBR) and the Colorado River Basin Salinity Control Forum for their support of the Paradox Valley survey and to Andrew Valdez and Fred Bunch (NPS) and the staff at Great Sand Dunes National Park and Preserve for their support of the San Luis Valley survey. This report was improved through reviews by Ben Drenth and Jeff Lucius (both USGS).

\section{References Cited}

Auken, E., Christiansen, A.V., Jacobsen, B.H., Foged, N., and Sørensen, K.I., 2005, Piecewise 1D laterally constrained inversion of resistivity data: Geophysical Prospecting, v. 53, p. 497-506.

Bankey, V., Grauch, V.J.S., and Fugro Airborne Surveys Corp., 2004, Digital aeromagnetic data and derivative products from a helicopter survey over the town of Blanca and surrounding areas, Alamosa and Costilla Counties, Colorado: U.S. Geological Survey Open-File Report 2004-1229-B, 8 p.

Carter, W.D., and Gualtieri, J.L., 1957, Preliminary geologic map of the Mount Peale 1 SE quadrangle, Montrose County, Colorado, and San Juan County, Utah: U.S. Geological Survey Mineral Investigations Field Studies Map MF-123, scale: 1:24,000.

Carter, W.D., Gualtieri, J.L., and Shoemaker, E.M., 1958, Preliminary geologic map of the Mount Peale 1 NE quadrangle, San Juan County, Utah, and Montrose County, Colorado: U.S. Geological Survey Mineral Investigations Field Studies Map MF-139, scale: 1:24,000.

Cater, F.W., Butler, A.P., and McKay, E.J., 1955, Geology of the Uravan quadrangle, Colorado: U.S. Geological Survey Geologic Quadrangle Map GQ-78, scale: 1:24,000.

Cater, F.W., 1955, Geology of the Naturita NW quadrangle, Colorado, U.S. Geological Survey Geologic Quadrangle Map GQ-65, scale: 1:24,000.

Cater, F.W., 1954, Geology of the Bull Canyon quadrangle, Colorado: U.S. Geological Survey Geologic Quadrangle Map GQ-33, scale: 1:24,000.

Chafin, D.T., 2002, Effect of the Paradox Valley Unit on the dissolved-solids load of the Dolores River near Bedrock, Colorado, 1988-2001: U.S. Geological Survey Water-Resources Investigation Report 02-4275, $6 \mathrm{p}$.

Christiansen, A.V., and Auken, E., 2012, A global measure for depth of investigation: Geophysics, v. 77, p. WB171-WB177.

Drenth, B.J., Abraham, J.D., Grauch, V.J.S., Labson, V.F., and Hodges, G., 2013, Digital data from the Great Sand Dunes airborne gravity gradient survey, south-central Colorado: U.S. Geological Survey Open-File Report 2013-1011, 5 p.

Drenth, B.J., Grauch, V.J.S., Bankey, V., and New Sense Geophysics, Ltd., 2009, Digital data from the Great Sand Dunes and Poncha Springs aeromagnetic surveys, south-central Colorado: U.S.

Geological Survey Open-File Report 2009-1089, 6 p.

Fitterman, D.V., and de Souza Filho, O.A., 2009, Transient electromagnetic soundings near Great Sand Dunes National Park and Preserve, San Luis Valley, Colorado (2006 field season): U.S. Geological Survey Open-File Report 2009-1051, 55 p.

Fitterman, D.V., and Grauch, V.J.S., 2010, Transient electromagnetic mapping of clay units in the San Luis Valley, Colorado: Proceedings of the 23rd SAGEEP, 2010 EEGS Annual meeting, April 11-15, 2010, p. 154-164.

Machette, M.N., Thompson, R.A., Marchetti, D.W., and Smith, R.S.U., 2013, Evolution of ancient Lake Alamosa and integration of the Rio Grande during the Pliocene and Pleistocene, in Hudson, M.R., and 
Grauch, V.J.S., eds., New perspectives on Rio Grande rift basins-From tectonics to groundwater: Geological Society of America Special Paper 494, p. 1-20.

McKay, E.J., 1955, Geology of the Red Canyon quadrangle, Colorado: U.S. Geological Survey Geologic Quadrangle Map GQ-58, scale: 1:24,000.

Reid, A.B., 1980, Aeromagnetic survey design: Geophysics, v. 45, no. 5, p. 973-976.

Rogers, K.L., Larson, E.E., Smith, G., Katzman, D., Smith, G.R., Cerling, T., Wang, Y., Baker, R.G., Lohmann, K.C., Repenning, C.A., Patterson, P., and Mackie, G., 1992, Pliocene and Pleistocene geologic and climatic evolution in the San Luis Valley of south-central Colorado: Palaeogeography, Palaeoclimatology, Palaeoecology, v. 94, p. 55-86.

Tweto, O., 1979, The geologic map of Colorado: Special Publication of the U.S. Geological Survey, Reston, Virginia, scale: 1:500,000.

Shoemaker, E.M., 1956, Geology of the Roc Creek quadrangle, Colorado: U.S. Geological Survey Geologic Quadrangle Map GQ-83, scale: 1:24,000.

Watts, K.R., 2000, Effects of the Paradox Valley Unit on dissolved solids, sodium, and chloride in the Dolores River near Bedrock, Colorado, water years 1988-98: U.S. Geological Survey WaterResources Investigations Report 00-4011, 8 p.

Webring, M.W., 1981, MINC_A gridding program based on minimum curvature: U.S. Geological Survey Open-File Report 81-1224, 11 p.

Weir, J.E., Jr., Maxfield, E.B., and Zimmerman, E.A., 1983, Regional hydrology of the Dolores River Basin, eastern Paradox Basin, Colorado and Utah: U.S. Geological Survey Water-Resources Investigations Report 83-4217, $62 \mathrm{p}$.

Withington, C.F., 1955, Geology of the Paradox quadrangle, Colorado: U.S. Geological Survey Geologic Quadrangle Map GQ-72, scale: 1:24,000. 